\title{
Cost Optimization of Earthwork Equipment Fleet by Productivity Analysis - Case Study of NH 50 Phase IV
}

\author{
Bhagyesh J. Chaudhari ${ }^{1}$, Prof. S. C. Tandale ${ }^{2}$, Prof. S. S. Deshmukh ${ }^{3}$ \\ ${ }^{1}$ PG Scholar, Trinity Academy Of Engineering and Management Research Center, Pune Maharashtra, India \\ ${ }^{2}$ Assistant. Professor, Trinity Academy Of Engineering and Management Research Center, Pune Maharashtra, India \\ ${ }^{3}$ Associate Professor, Trinity Academy Of Engineering and Management Research Center, Pune Maharashtra, India
}

\begin{abstract}
Construction sector particularly infrastructure projects like roads and dams etc. employees various type of construction equipment in large numbers. In India Excavators, dumpers, dozers, Motor graders, soil compactors etc are most commonly used earth work equipments on road project. These equipments work in synchronization with each other. Construction equipment are the major resource in infrastructure projects. Construction equipments occupy major portion of project finance. But improper utilization of such resource leads to loss of productivity, ultimately affecting profit. This paper tries to shows how productivity and profit optimization of these equipments can be achieved. To perform these optimization production capacity and cost of equipments, idle period is taken into consideration. To validate the results, case study of $\mathrm{NH5O}$ is taken and it is found that there is increase in profit.
\end{abstract}

Keywords: Fleet, Construction equipments, production potential, idle period, cost optimization

\section{Introduction}

In most of the public works operations equipment is largest support function. The volume of work now a days are getting increases. The projects are getting very big. Moreover large and highly competitive markets for infrastructure projects especially BOT type of contract, enforces the contractors to complete the project as early as possible to start regaining the investments. To fulfill the completion date of such mega projects contractors are involving various types of construction equipments in large numbers. These equipments comes under various sizes and from number of different manufacturers. There are various types of equipment are being used on sites to day like excavating equipments like excavator, loading equipments like front loaders, hauling equipments like dumpers, spreading equipments like dozers, leveling equipments like motor graders, compacting equipments like soil compactors, lifting equipments like cranes etc.

These equipments work in support to each other to complete the works. This group of equipment together is known as fleet. A large group of equipments working together engaged in the same activity, under the same administration, performing their individual operations to complete that particular activity is called as a construction equipment fleet.

\subsection{Equipment Fleet}

A fleet can be homogenous fleet of similar equipments or heterogeneous fleets of group of different equipments when these equipments work together it develop a complex situation as number of variables increases. This complexity give raise the use of EMS.

\subsection{Equipment management system (EMS)}

EMS solves the following problems accompanied with fleets of various equipments.

\subsubsection{Equipment selection and optimization}

Equipment selection means which type of equipment to be assigned for this particular type of work. As we discussed there are large variety of equipment are available to do project, it is very important to choose proper equipment which will be feasible financially and functionally.

Equipment optimization means assigning optimum number of equipment so as to reduce the idle period of this equipment.

\subsubsection{Productivity analysis and monitoring}

This is another important element regarding the production calculation of the equipments. It do the study of cycle times, loading capacity, performances of loading. Basically this component works to find out and optimize the production potential of equipments.

This EMS make easy to monitor the production potential in real time using latest data communication technologies.

\subsubsection{Position and material monitoring}

When these equipment work they work simultaneously. This develops congestion on hauling route. Also it equipment are not positioned where they should be then it hamper the activity. This component helps to monitor of these equipments so as to reduce congestion on hauling roads at loading sites.

But this is not limited up to position monitoring only. This also helps to monitor which type of material and in which quantity the equipment is shifting. This is very important from safety point of view of both equipments and operators. This also analyzes performance of the overall fleet which gives managers exact idea about the productivity of the fleet. 


\section{International Journal of Science and Research (IJSR) \\ ISSN (Online): 2319-7064}

Index Copernicus Value (2013): 6.14 | Impact Factor (2015): 6.391

\subsection{Research motivation}

The construction industry has undergone automation and still is. Contractors are employing more and more equipments to get job done. And they are being successful. Top managements are trying to provide best working environment to its working executives. But equipments are still used and managed on the basis of the experience. These methods are resulting in production losses, delays which ultimately lead to loss in profit of company.

\subsection{Aim of paper}

This paper aims towards optimizing the cost of fleet at site using productivity analysis.

\section{Methodology}

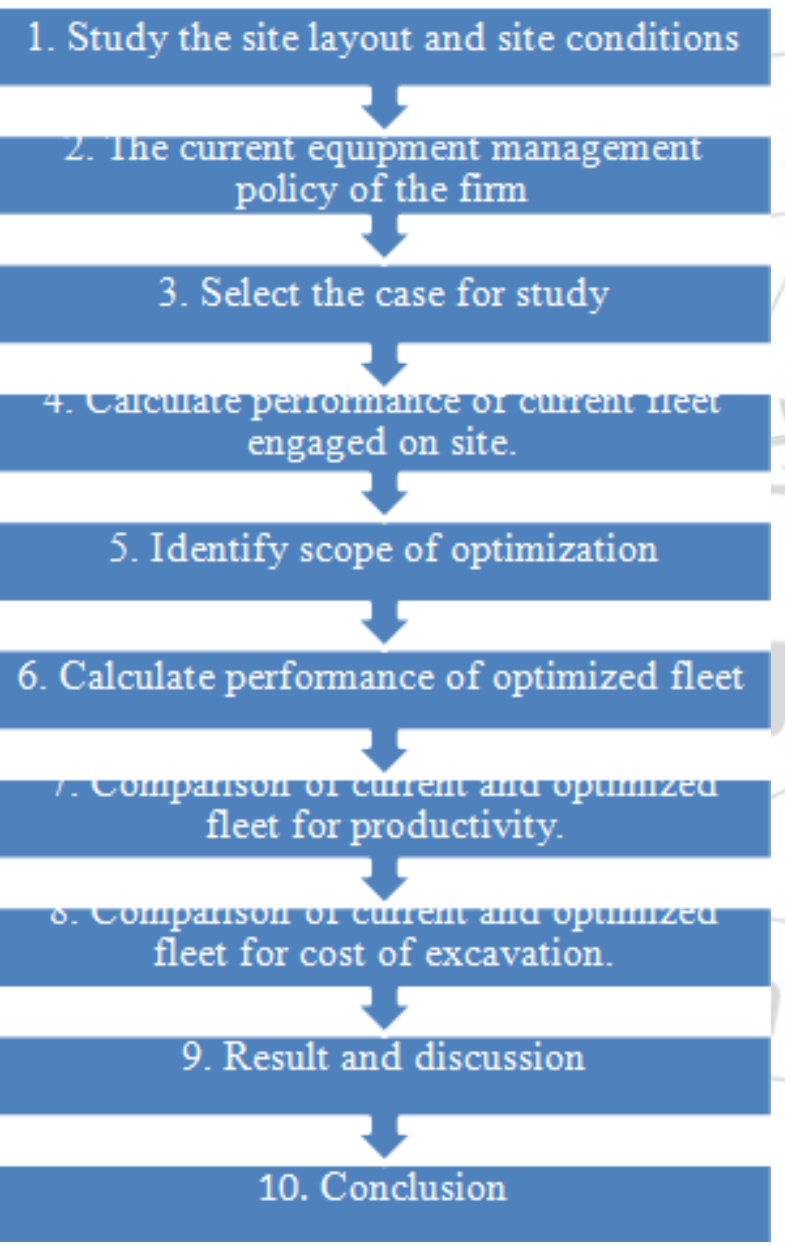

\section{Case Study}

For this paper case study of national highway 50 Sinnar to nashik road from chainage $177 / 00$ to $201 / 350$ is taken. This is 4 layning project of whole NH50 form Pune to nashik. It is divided in 4 phases each phase being constructed by different subcontract.

Name of department/authority: The chief engineer, National Highway (P.W.D) Maharashtra, kokan Bhawan, Navi Mumbai-400614
Cost of project (INR): Rs. 313.00 Crores.

Date of completion: 2 years after appointed date.

\subsection{Economics of equipment:}

Cost of equipment comprises the major part of economy of the project. It is very important to know the equipment economy in order to optimize the expense spend on these equipments, total cost required to operate these equipments.

Economy of construction equipment can be divided in two parts one of them being ownership cost and another being operation cost.

\subsubsection{Ownership cost:}

Every equipment enters in organization's resource pool through purchase or lease or renting basis. The ownership cost is sum of various expense required to owning the equipment.

- Purchase cost at showroom.

- If money is borrowed from then rate of interest.

- Taxes as property.

- Insurance against the security.

- Storage cost.

- Some time transportation charges are also becomes part of ownership cost.

Ownership cost is have to pay weather equipment is operating nor not. It is cost related with finance of equipment and not the expenses required for operating it. From the well maintain record of previous equipments it easy to understand relatively accurate ownership cost.

Annualized purchase can said as the cost equivalent to purchase cost for every year calculated with some rate of interest on capital.

\subsubsection{Operating cost:}

Operating cost of equipment is expense required to operate the equipment. The difference between ownership cost and operating cost is that ownership cost is there whether equipment is working or static but operating cost is required only when the equipment is under operation.

Like ownership cost, operating cost also comprises various cost like

- Minor maintenance charges

- Fuel and lubrication cost

- Operator wages

- Repair charges

In this project following operating costs are considered

- Fuel Consumption

- Engine oil

- Hydraulic oil 


\section{International Journal of Science and Research (IJSR)}

ISSN (Online): 2319-7064

Index Copernicus Value (2013): 6.14 | Impact Factor (2015): 6.391

- Tyres expenses

- Coolant expenses

- Filter expenses

Table 1: Per hour cost of equipment

\begin{tabular}{|c|c|}
\hline Equipment & Cost per hour \\
\hline Volvo EC210 B & 1043.05 \\
\hline Lnt komatsu PC 200 & 923.88 \\
\hline TATA haiwa 2518 & 474.24 \\
\hline Layland 2516 & 452.13 \\
\hline $\begin{array}{c}\text { Volvo SD110 soil } \\
\text { compactor }\end{array}$ & 713.54 \\
\hline Volvo EC210 B & 1043.05 \\
\hline
\end{tabular}

\subsection{Production analysis:}

Production capacity is very important parameter in case of fleet management. The production capacity of each and every equipment in fleet is important as it will give the idea about the capacity of fleet as whole. It is very important to know the capacities of our equipments in order to optimize them.

The productivity is dependent on various factors like distance, time, speed, capacity, cycles etc. Universally used unit for productivity is $\mathrm{m} 3 \mathrm{per} / \mathrm{hr}$.

Parameters of productivity for various equipments:

\subsubsection{Capacity:}

It is the volume capacity of equipment with which it operates. Capacity of bucket of excavator, capacity of body of tippers these are the examples of capacity of equipment

\subsubsection{Efficiency:}

It is the ability of equipment operator to do the work. It shows how much actually the operator works in one working day. The operational efficiency of construction equipment, which refers to the ratio of the productive work time of equipment to its total operating time (Nichols and Day 2005)

\subsubsection{Fill factor:}

It is also refer as bucket efficiency factor. Bucket handles wide range of materials form black cotton soil to Murum, rocks to boulders. Different material fill differently in bucket loose material will have less voids so volume will be more whereas rock etc will fill at less volume that is the efficiency will be less. This fill factor will give how specific material will fill.

\section{A) Productivity of Excavator:}

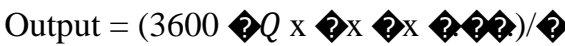

$\mathrm{Q}=$ Capacity of bucket in $\mathrm{m} 3$ (loose state).

$\mathrm{F}=$ Fill factor. $\mathrm{E}=$ efficiency

$\mathrm{T}=$ Cycle time of excavator.

V.C. $=$ Volume correction factor.

\section{B) Productivity of Tipper:}

Output $=(\mathrm{V} * 60) / \mathrm{T}$

$\mathrm{V}=$ Volume of tipper $\mathrm{m} 3$

$\mathrm{T}=$ Tipper cycle time ( $\mathrm{min})$

\section{C) Productivity of Dozer:}

Output $=((60 \times L) /$ ? $) \times f \times \mathrm{E}$

$\mathrm{T}=$ push cycle time $(\mathrm{min})$

$f=$ material type correction factor

$\mathrm{E}=$ efficiency

$\mathrm{L}=$ blade load (m3)

\section{D) Productivity of Roller:}

$$
\begin{aligned}
& \text { Output }=(\geqslant \times \text { P } L \times>0.9) / n \\
& \mathrm{~W}=\text { compacted width } \\
& \mathrm{S}=\text { avg. roller speed } \\
& \mathrm{L}=\text { compacted lift thickness } \\
& \mathrm{E}=\text { Efficiency. } \\
& \mathrm{n}=\text { no. of roller passes. }
\end{aligned}
$$

Table 2: Production potential of current fleet

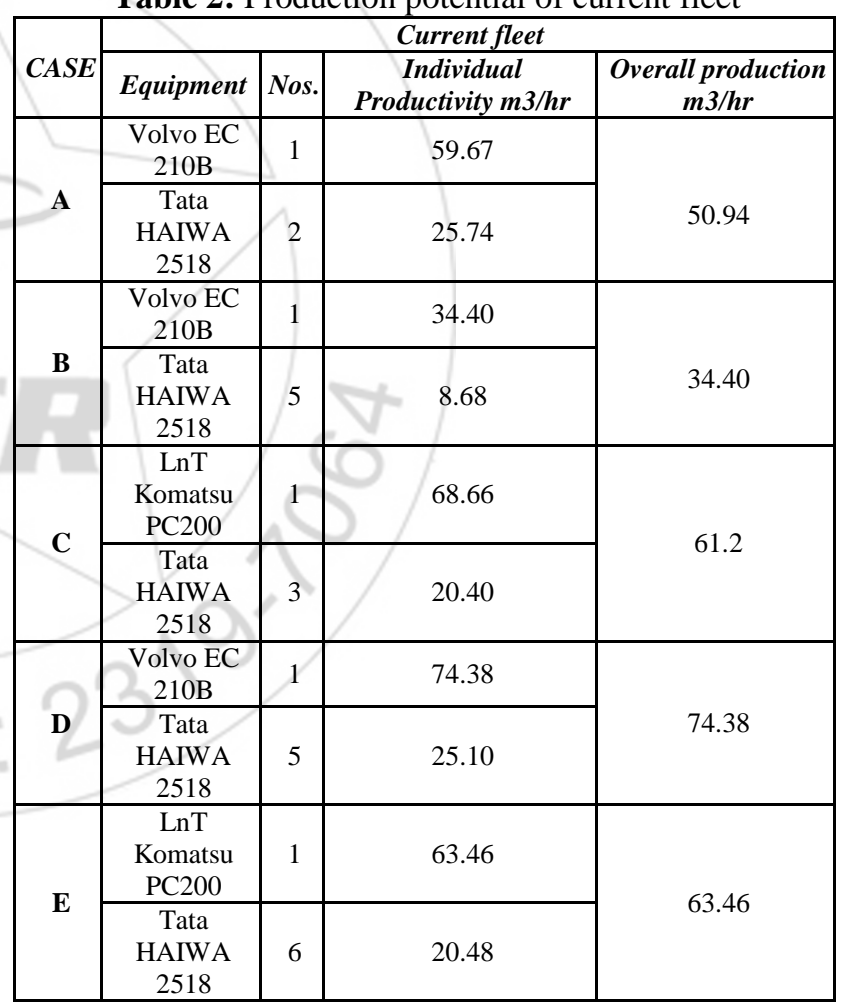

\subsection{Fleet optimization:}

Tipper optimization can be explained as employing near to exact number of tipper at work so that the unnecessary loss of productivity can be controlled. This is achieved by calculating optimum number of units. By using following formula no. of units can be found out.

Optimum no. of tipper $(\mathbf{n})=$ tipper cycle time / tipper loading time 
International Journal of Science and Research (IJSR)

ISSN (Online): 2319-7064

Index Copernicus Value (2013): 6.14 | Impact Factor (2015): 6.391

Table 3: Optimized numbers and production potential of optimizes fleet

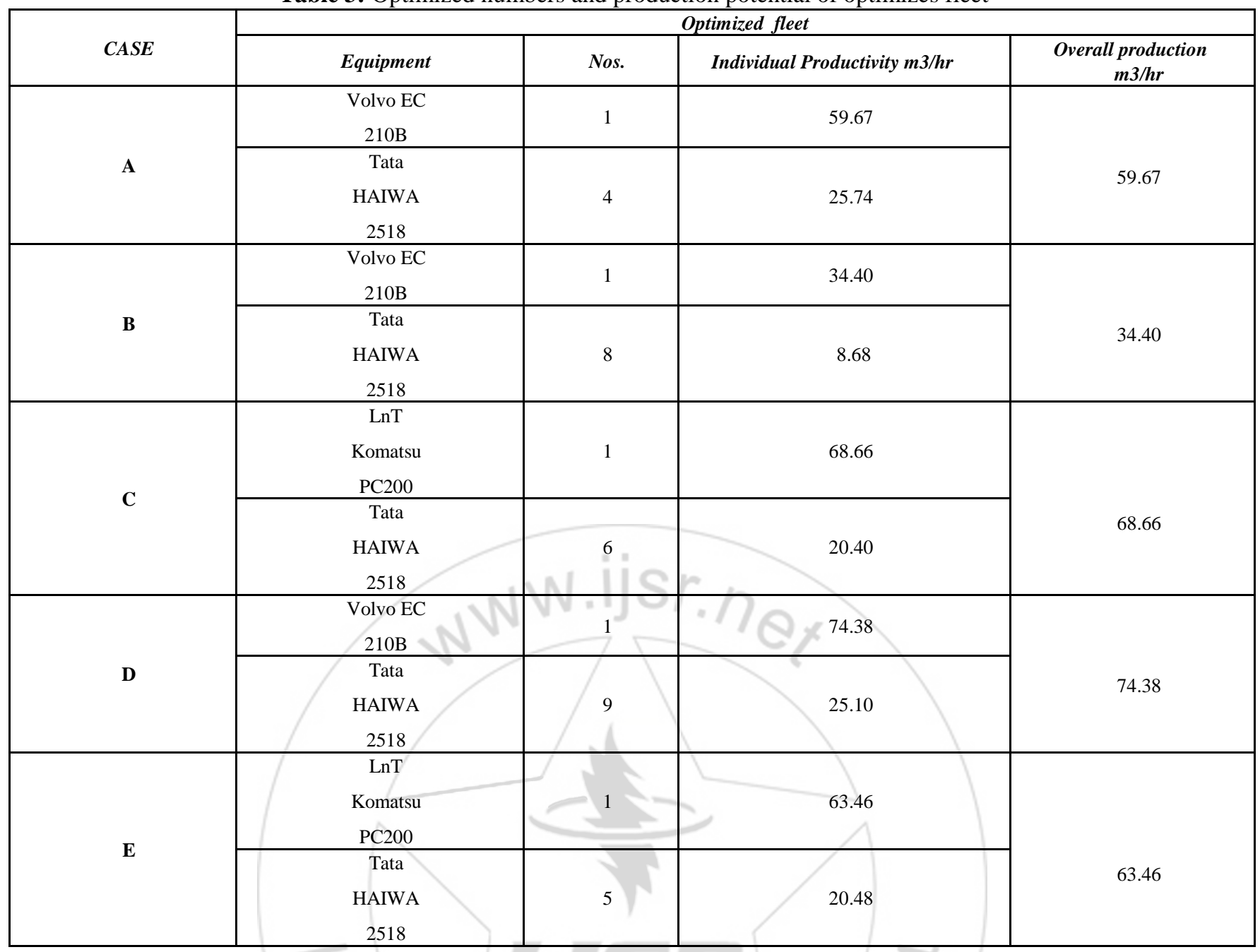

Table 4: Cost of excavation of current fleet

\begin{tabular}{|c|c|c|}
\hline Case & Quantity $\boldsymbol{( m}^{3)}$ & Cost of Excavation( Rs) \\
\hline A & 2453.84 & 85585.98 \\
\hline B & 1350.96 & 50618.48 \\
\hline C & 1652.40 & 45231.40 \\
\hline D & 10150.00 & 149088.63 \\
\hline E & 2639.80 & 33537.16 \\
\hline
\end{tabular}

Table 5: Cost of excavation of optimized fleet

\begin{tabular}{|c|c|c|}
\hline Case & Quantity $(\mathbf{m 3})$ & Cost of Excavation (Rs) \\
\hline A & 2453.84 & 37655.09 \\
\hline B & 1350.96 & 29507.75 \\
\hline C & 1652.40 & 18325.33 \\
\hline D & 10150.00 & 58954.20 \\
\hline E & 2639.80 & 27947.64 \\
\hline
\end{tabular}

\section{Result and Discussion}

\subsection{Optimize fleet:}

The following table shows the o fleet of TATA Hyva $14.95 \mathrm{~m} 3$ for each case under consideration. The table gives the difference of number of hauling units between current fleet engaged on site and the optimize fleet that is derived from the calculation performed.
Table 6: Nos no hauling units

\begin{tabular}{|c|c|c|}
\hline Case & Current Fleet & Optimized Fleet \\
\hline A & 2 Nos. & 4 Nos. \\
\hline B & 5 Nos. & 8 Nos \\
\hline C & 3 Nos. & 6 Nos. \\
\hline D & 5 Nos. & 9 Nos. \\
\hline E & 6 Nos. & 5 Nos. \\
\hline
\end{tabular}

\subsection{Cost of excavation:}

Total Cost of excavation is nothing but the cost required to complete the processes of excavation and hauling. This can be found out by using following formula

\section{Volume 5 Issue 5, May 2016}




\section{International Journal of Science and Research (IJSR) \\ ISSN (Online): 2319-7064}

Index Copernicus Value (2013): 6.14 | Impact Factor (2015): 6.391

$\mathrm{TC}=\mathrm{M}(\mathrm{c})(\mathrm{Hn}+\mathrm{He}) / \mathrm{N}(\mathrm{sh}) 60$

\subsection{Production potential:}

After the productivity analysis for both cases following table shows the difference in production potential of the both fleets i.e. current and optimized.

Table 7: Cost of excavation of current fleet

\begin{tabular}{|c|c|c|c|c|c|}
\hline \multirow[b]{2}{*}{ Case } & \multicolumn{2}{|c|}{ Current Fleet } & \multicolumn{2}{|c|}{ Optimize fleet } & \multirow{2}{*}{$\begin{array}{c}\% \\
\text { increase in } \\
\text { productivity }\end{array}$} \\
\hline & $\begin{array}{c}\text { Productivity } \\
\text { m3 }\end{array}$ & Type & $\begin{array}{c}\text { Productivity } \\
m 3\end{array}$ & Type & \\
\hline \multirow{2}{*}{ A } & \multirow{2}{*}{50.94} & Tipper & \multirow{2}{*}{59.67} & Excavator & \multirow{2}{*}{$17.13 \%$} \\
\hline & & control & & control & \\
\hline \multirow{2}{*}{ B } & \multirow{2}{*}{34.4} & Excavator & \multirow{2}{*}{34.4} & Excavator & \multirow{2}{*}{ - } \\
\hline & & control & & control & \\
\hline \multirow{2}{*}{$\mathrm{C}$} & \multirow{2}{*}{61.2} & Tipper & \multirow{2}{*}{68.66} & Excavator & \multirow{2}{*}{$12.18 \%$} \\
\hline & & control & & control & \\
\hline \multirow{2}{*}{$\mathrm{D}$} & \multirow{2}{*}{74.38} & Excavator & & Excavator & \multirow{2}{*}{-} \\
\hline & & control & & control & \\
\hline \multirow{2}{*}{$\mathrm{E}$} & \multirow{2}{*}{63.46} & Excavator & & Excavator & \multirow{2}{*}{ - } \\
\hline & & control & & control & \\
\hline
\end{tabular}

Where,

$\mathrm{M}=$ Project quantity (M3)

$\mathrm{C}=$ tipper corrected cycle time $(\mathrm{min}) \mathrm{Hn}=$ tipper $\mathrm{O} \& \mathrm{O}$ cost

$\mathrm{He}=$ Excavator $\mathrm{O} \& \mathrm{O}$ cost

$\mathrm{N}=$ Number of tipper

$\mathrm{Sh}=$ Size of tipper $(\mathrm{M} 3)$

\subsection{Cost comparison:}

Following table shows the comparison between total cost of excavation between current fleet and optimized fleet. It can be seen that the cost has decrease in case of optimized fleet. This happened because of change of fleet from tipper control to excavator.

Table 8: Cost of excavation of optimized fleet

\begin{tabular}{|c|c|c|c|}
\hline Case & $\begin{array}{c}\text { Cost of current } \\
\text { fleet }\end{array}$ & $\begin{array}{c}\text { Cost of optimized } \\
\text { fleet }\end{array}$ & $\begin{array}{c}\% \text { reduction in } \\
\text { cost }\end{array}$ \\
\hline A & 85585.98 & 37655.09 & 56.00 \\
\hline B & 50618.48 & 29507.75 & 41.71 \\
\hline C & 45231.40 & 18325.33 & 59.49 \\
\hline D & 149088.63 & 58954.20 & 60.46 \\
\hline E & 33537.16 & 27947.64 & 16.67 \\
\hline Total & 364061.66 & 172390.013 & 52 \\
\hline
\end{tabular}

\section{Conclusion}

From the above discussed results it can be concluded that:

The optimized fleet gives more productivity than current fleet employed at site.

Cost comparison shows the up to $50 \%$ reduction in the cost of excavation for optimized fleet than current fleet.

\section{References}

[1] Amir Tavakoli, Johannes J. Masehi and Cynthia S. Collyard, FLEET: Equipment Management System, Journal of Management in Engineering, Vol.6, 1990, 211-220.

[2] Douglas D Gransberg, Optimizing Haul Unit Size And Number Based On Loading Facility Characteristics, Journal Of Construction Engineering And Management, 1996, 248253.

[3] Serji Amirkhanian and Nancy J. Baker, Expert System For Equipment Selection For Earth-Moving Operations, Journal of construction engineering and management, 1992, 318331.

[4] Nipesh Pradhanga and Jochen Teizer, Automatic spatiotemporal analysis of construction site equipment operations using GPS data, Automation in Construction, 2013, 107-122

[5] Simon D. Smith, Earthmoving Production Estimation using Linear Regression Techniques, Journal of construction engineering and management, 1999, 133-141.

[6] C William Ibbs and Kenneth R. Tarveer, Integrated Construction Preventive Maintenance System, Journal of Construction Engineering and Management, 1984, 43-59.

[7] Thanapun Prasertunganian and B.H.W Hadikusumo, Modeling the Dynamics of Heavy Equipment Management Practices and Downtime in Large Highway Contractors, Journal of Construction Engineering and Management, 2009, 939-947.

[8] Y.R. Anbhule, Prof. M.B. Kumthekar, 3D Equipment Management System for Highway Construction Projects: Conceptual Design, Journal of Mechanical and Civil Engineering, 2013, 1-4

[9] IS.11399.1.1985

[10] Construction planning, equipment, methods - Peurifoy, Schnexyder, shapira

[11] Norms for Production of Construction Machinery and Manual Labour- V.B. Pandit 